\title{
PERUBAHAN MODEL DAN KARAKTERISTIK PEMBELAJARAN PENDIDIKAN AGAMA ISLAM DI MASA PANDEMI COVID-19
}

\author{
Arista Aulia Firdaus ${ }^{1}$, *Unik Hanifah Salsabila ${ }^{2}$, Sarifa Sintia Mahdalina ${ }^{3}$ \\ 1,2,3 Universitas Ahmad Dahlan Yogyakarta, Indonesia \\ *email korespondensi: unik.salsabila@pai.uad.ac.id
}

\begin{abstract}
The COVID-19 pandemic has changed the model and characteristics of Islamic education learning that has been going on so far. The future of Islamic education is undergoing changes so it is feared that it will experience a setback in education. Work From Home (WFH) policies, social and physical distancing, the process of Teaching and Learning Activities (KBM) using an online system also enlivened the dynamics of Islamic education. This is in accordance with the issuance of an SKB (joint decree) of four ministers regarding the implementation of learning at the beginning of the 2020/2021 school year, and the Decree of the Director General of Education Number 2791 of 2020 concerning emergency curriculum guidelines for madrasas to support learning amid the Covid-19 pandemic. therefore. The ministerial decree above indicates that it is time for reorientation and the role of Islamic education to start accelerating its learning format. This kind of adaptation is a must in responding to the challenges of Islamic education in the COVID-19 pandemic.
\end{abstract}

Keywords: Islamic Religious Education, Changes in Learning, Covid-19 Pandemic

\begin{abstract}
Abstrak: Pandemi COVID-19 telah merubah model dan karakteristikpembelajaran pendidikan Agama Islam yang berlangsung selama ini. Masa depan pendidikan Agama Islam, mengalami perubahan sehingga dikhawatirkan akan mengalami kemunduran dalam pendidikannya. Kebijakan Work From Home (WFH), social and physical distancing, proses Kegiatan Belajar Mengajar (KBM) menggunakan sistem daring (online) turut meramaikan dinamika pendidikan Agama Islam. Hal inisesuaidengan penerbitan SKB (surat keputusan bersama) empat menteri tentang penyelenggaran pembelajaran di awal tahun pelajaran 2020/2021, dan Surat Keputusan Dirjen Pendis Nomor 2791 Tahun 2020 tentang panduan kurikulum darurat bagi madrasah untuk mendukung pembelajaran di tengah pandemi Covid-19 menjadi bukti untuk itu. Keputusan kementerian di atas mengindikasikan bahwa sudah waktunya reorientasi dan peran pendidikan Islam mulai mengakselerasi format pembelajarannya. Pengadaptasian semacam ini merupakan sebuah keharusan dalam menjawab tantangan pendidikan Agama Islam di pandemi COVID-19.
\end{abstract}

Kata Kunci: Pendidikan Agama Islam, PerubahanPembelajaran, Pandemi Covid-19

\section{PENDAHULUAN}

Pandemi COVID-19 benar-benar telah memukul mundur semua lini kehidupan manusia dan pendidikan Islam pun menjadi salah satu bidang krusial yang sangat terdampak. Masa pandemi ini juga berdampak pada dunia pendidikan, yang mana untuk menghindari terkena virus sekolah diadakan online (pembelajaran daring), yang mana seluruh proses kegiatan belajar mengajar dilakukan dengan jarak jauh secara online. Mulai dari pemberian materi dan tugas, 
pengerjaan dan pengumpulan tugas hingga pembagian hasil belajar (raport)(Suyanto et al., 2008).

Dalam pembelajaran daring ini sarana utama yang dibutuhkan adalah teknologi berbasis internet. Dalam UU No. 20 Tahun 2003 pasal 1 ayat 2 menyatakan bahwa "Pendidikan nasional yang harus berdasarkan pancasila dan Undang-Undang Dasar Negara Republik Indonesia tahun 1945 yang menganut nilai-nilai agama, harus tegas tanggap pada tuntutan akhir zaman dan kebudayaan nasional Indonesia." Sesuai dengan undang-undang di atas, bahwasannya pendidikan selain harus berdasarkan pada pancasila dan Undang-Undang Dasar dan menganut nilai-nilai agama, juga harus tegas tanggap pada tuntutan akhir zaman. Tuntunan yang peneliti maksud disini adalah tegas dan tanggap pada permasalahan ditengah pandemi Covid-19, sehingga walaupun adanya pandemi dan social distancing proses Kegiatan Belajar Mengajar (KBM) masih bisa terus dilakukan.

Masa depan pendidikan Agama Islam akan terancam mengalami perubahan jika tidak adanya langkah-langkah yang baik untuk merespon pandemi ini. Terlebih, kebijakan Work From Home (WFH), social and physical distancing, proses Kegiatan Belajar Mengajar (KBM) menggunakan sistem daring (online) turut meramaikan dinamika pendidikan Islam. Sebagai bentuk problem solving dari kebijakan di atas, salah satunya adalah melakukan perubahan model dan karakteristik pendidikan Islam dalam bingkai new normal education (adaptasi baru dalam bidang pendidikan).

Kebijakan pembelajaran jarak jauh menjadikan tantangan tersendiri bagi pendidik Agama Islam untuk melakukan pembelajaran dengan menggunakan teknologi (Pratiwi Wiwik, 2017). Definisi dari pembelajaran jarak jauh adalah pendidikan formal berbasiskan lembaga dimana kelompok belajar terpisah dan sistem telekomunikasi digunakan untuk menghubungkan peserta belajar, sumber belajar, dan instruktur (Chaeruman, 2013). Dengan adanya pembelajaran jarak jauh guru secara otomatis akan belajar teknologi. Mengingat guru merupakan garda terdepan dunia pendidikan yang harus mampu menyesuaikan dan memanfaatkan teknologi dalam pembelajaran (Joenaidy, $2020: 12$ ). 
Bahkan pendidik pada pembelajaran jarak jauh dituntut siap untuk melakukan pembelajaran daring secara efektif kepada peserta didik dan memiliki kreativitas dalam proses mengajar (Suharwoto, 2020). Pembelajaran jarak jauh mengajarkan guru harus cepat merespon untuk siap terhadap perubahan serta belajar memahami digital. Pembelajaran jarak jauh yang dilakukan secara daring mengikuti fakta seharusnya menjadi solusi untuk dunia pendidikan. Pembelajaran daring menjadi salah satu bentuk inovasi dunia pendidikan dalam menjawab tantangan problematika saat ini (Rosali, 2020). Akan tetapi faktanya dunia pendidikan di Indonesia tidak dapat disamaratakan mengenai pembelajaran daring dikarenakan wilayah di Indonesia kondisinya beragam dan kendala yang dihadapi pun berbeda (Khasanah et al, 2020).

Pembelajaran dalam pendidikan agama islam dengan pendidikan pada umumnya, terkadang mempunyai persamaan dan juga perbedaan. Persamaan akan timbul karena sama-sama berangkat dari dua arah pendidikan yakni dari diri manusia yang memang fitrahnya untuk melakukan proses pendidikan, kemudian dari budaya yakni masyarakat yang memang menginginkan usaha warisan nilai, maka semua memerlukan pendidikan.

Pembelajaran jarak jauh bagi guru maupun siswa merupakan tantangan besar. Tantangan bagi guru adalah bagaimana mampu mengajarkan siswanya yang memiliki kecerdasan dan penangkapan yang berbeda-beda, gaya belajar yang beraneka ragam, serta solutif ketika siswanya mengalami hambatan dalam proses pembelajaran jarak jauh. Hal tersebut menjadi peluang guru untuk memahami kondisi dan situasi murid serta melakukan tindakan yang tepat untuk memberikan pengajaran maupun pelayanan. Sehingga disini guru memiliki tantangan dan peluang juga untuk mempelajari teknologi baik visual maupun audio visual. Inovasi-inovasi dalam teknologi informasi ini harusnya mendorong guru untuk mengembangkan kompetensi dan pencerahan khususnya guru Pendidikan Agama Islam (Nuryana, 2019).

Tujuan dari penelitian ini adalah untuk mendeskripsikan perubahan model dan karakteristik pembelajaran pendidikan Agama Islam di masa pandemic Covid-19. Salah satu dari perubahan model dan karakterisitk ini dilihat dari proses pembelajaran melalui e-learning yang mengedepankan keefisienan dalam belajar 
agar mahasiswa mendapat pengajaran yang penuh meski tidak harus bertatap muka, juga bisa diakses di mana saja, kapan saja, sesuai dengan tugas yang diberikan oleh dosen biasanya terjadwal dengan batas waktu yang ditentukan sehingga model dan karakteristik ini dapat sesuai dengan situasi saat ini.

\section{METODE}

Penelitian ini menggunakan metode penelitian kualitatif dengan jenis penelitian deskriptif. Jenis penelitian ini dimaksud untuk menggambarkan peristiwa atau kejadian tertentu. Pengumpulan data dalam penelitian ini lebih merujuk kepada kata-kata atau gambaran dan tidak menekankan kepada angka.

Penelitian ini mengguakan data sekunder berupa hasil studi pustaka berupa artikel, jurnal, buku, dan lain-lain. Setelah peneliti mengumpulkan informasi dan data, peneliti akan mereduksi data tersebut untuk memfokuskan kepada hal-hal, materi-materi yang penting dan dianggap relevan dengan penelitian yang ditulis. Kemudian peneliti melakukan pengumpulan informasidan memfokuskan materi, peneliti akan mendeskripsikan dan menarik hasil kesimpulan dalam penelitian yang telah dilakukan untuk menjelaskan permasalahan yang akan dijelaskan.

Dalam menganalisa data hasil penelitian, peneliti menggunakan Miles, Huberman \& Saldana (2014: 31) yang terdiri dari tahapan pengumpulan data, kondensasi data, penyajian data dan penarikan kesimpulan. Sedangkan untuk mendapatkan keabsahan data, peneliti menggunakan bebeapa teknik yaitu peningkatan ketekunan, diskusi teman sejawat, pengecekan angota dan triangulasi.

\section{HASIL DAN PEMBAHASAN}

\section{Hasil}

Kementerian Agama selaku penanggung jawab penyelenggaraan pendidikan Agama Islam telah menerbitkan panduan kurikulum darurat bagi madrasah untuk mendukung pembelajaran ditengah pandemi COVID-19. Hal ini tertuang dalam Surat Keputusan Direktur Jenderal Pendidikan Islam Nomor 2791 Tahun 2020. Panduan kurikulum ini berlaku bagi tingkat pendidikan madrasah mulai dari Raudhatul Athfal (RA), Madrasah Ibtidaiyah (MI), Madrasah Tsanawiyah (MTs), hingga Madrasah Aliyah (MA) (Aji, 2020). 
Kurikulum darurat ini lebih menekankan soal pengembangan karakter, akhlak mulia, ubudiyah dan kemandirian siswa. Walaupun begitu pemenuhan aspek kompetensi, baik dasar maupun inti, tetap menjadi perhatian. Di era pandemi, maka tidak ada pilihan lain bagi pendidikan Islam kecuali merevitalisasi peran pendidikan Islam (new role of Islamic education).

Pendidikan Islam memainkan peran konstruktif dalam mencapai tujuan pembangunan. Sekolah Islam berperan penting dalam membentuk karakter kepribadian peserta didik dan mengoptimalkan segala potensi yang dimilikinya. Maka, pendidikan Agama Islam tidak hanya berkontribusi bagi pribadi dan pengembangan kapasitas peserta didik, tetapi juga meningkatkan rasa percaya diri dan kohesi sosial di tengah perbedaan Mengabaikan pendidikan agama termasuk pendidikan Islam berarti mengabaikan masa depan ([11] C, 2020).

Pandemi Covid-19 mengharuskan pembelajaran diselenggarakan secara daring di rumah. Bahkan, saat ini Nadiem Makarim, Mendikbud RI tengah menggodok Pembelajaran Jarak Jauh (PJJ) yang berfokus pada tiga komponen, yakni numerasi, lierasi dan pendidikan karakter). Menurutnya ketiganya adalah pondasi dasar. Penerbitan Surat Edaran Mendikbud Nomor 4 tahun 2020 tentang pelaksanan kebijakan pendidikan dalam masa darurat penyebaran Covid-19 adalah bukti untuk itu.

Penggunaan belajar online (daring) dalam pendidikan terus meningkat. Para siswa tidak hanya lagi memiliki akses ke buku cetak, tetapi juga pada materi pendidikan yang terletak jauh melampaui bangunan sekolah salah satunya internet Sedangkan menurut Brace dalam teknologi internet sebagai media pembelajaran merupakan jaring global yang menghubungkan beribu-ribu bahkan berjuta jaringan komputer (local wide areal network) dan komputer pribadi (stand alone), yang memungkinkan setiap komputer terhubung kepadanya bisa melakukan komunikasi satu sama lain(Arifa, 2020).

Berdasarkan hal tersebut bahwa pembelajaran online dan teknologi internet di atas bahwa penggunaan teknologi berbais internet sangat dibutuhkan dan terus meningkat, diharapkan kebijakan sekolah terkait pembelajaran berbasis Web dan kebebasan setiap guru untuk menggunakan aplikasi lain yang dirasa lebih memudahkan dalam proses Kegiatan Belajar Mengajar (KBM) online, dapat 
membantu mengatasi permasalahan pembelajaran daring selama masa pandemi untuk mencapai indikator-indikator yang dituju dalam pembelajaran(Inas Wydianuratikah, 2020).

Beberapa poin penting dari SE (surat edaran) tersebut yang berhubungan dengan perubahan model dan karakterisitk pembelajaran yakni :

(1) Belajar dari rumah melalui pembelajaran daring/ jarak jauh berbasis web dilaksanakan untuk memberikan pengalaman belajar yang bermakna bagi siswa, tanpa terbebani tuntutan menuntaskan seluruh capaian kurikulum untuk kenaikan kelas maupun kelulusan;

(2) Belajar dari rumah dapat difokuskan pada pendidikan kecakapan hidup antara lain mengenai pandemi Covid-19;

(3) Aktivitas dan tugas pembelajaran belajar dari rumah dapat bervariasi antar siswa, sesuai minat dan kondisi masing-masing, termasuk mempertimbangkan kesenjangan akses/ fasilitas belajar dari rumah;

(4) Bukti atau produk aktivitas belajar dari rumah diberi umpan balik (feedback) yang bersifat kualitatif dan berguna bagi guru, tanpa diharuskan memberi skor/ nilai kuantitatif. Semua hal ini tentu mensyaratkan sumber daya manusia (SDM) pendidikan yang mumpuni. Peningkatan kualitas SDM adalah hal mutlak yang harus dituntaskan.

\section{Pembahasan}

Pembelajaran berbasis web merupakan suatu kegiatan pembelajaran yang memanfaatkan media situs (website) yang bisa diakses melalui jaringan internet. Pembelajaran berbasis web atau yang dikenal dengan web based learning merupakan salah satu jenis penerapan dari pembelajaran e-learning (BUDI \& Anshori, 2020). Dalam penggunaan teknologi internet berbasis web ini sekolah memanfaatkannya condong kepada pengambilan (download) materi dan tugastugas siswa

Peubahan dalam model dan karakteristik pada Pendidikan Agama Islam di tengah pandemi harus dilihat dalam tiga hal, yaitu penalaran Islam (Islamic reasoning) berbasis Alquran dan al-Hadits, sumber daya manusia (human needs) dan teknologi. 
Pertama, pendidikan Islam tidak terlepas dari Islamic source sebagai basis pengembangannya. Al-Quran dan al-Hadits telah diejawantahkan sebagai ruh pendidikan Islam. Perumusan kurikulum dan berbagai daya dukung pendidikan Islam diilhami oleh sumber primer ajaran Islam.

Kedua, human needs. Kompetensi dan kapabilitas sumber daya manusia menjadi faktor sentral (main factor) dalam pendidikan Islam. Perubahan zaman meniscayakan pendidikan Islam yang adaptif. Pendidikan Islam tidak boleh "berjalan di tempat" mengikuti arus. Pendidik utamanya memainkan peran sebagai pembentuk kualitas manusia. Penguasaan kompetensi pedagogik, kepribadian, profesional, dan sosial menjadi suatu keniscayaan(Wahyono et al., 2020).

Ketiga, teknologi. Suasana pandemi Covid-19 mengharuskan - untuk tidak mengatakan memaksakan - proses pembelajaran dilakukan secara daring. Seluruh institusi pendidikan mulai tingkat dasar hingga perguruan tinggi diminta untuk menghentikan proses perkuliahan tatap muka (luring). Sebagai gantinya dilakukan secara jarak jauh. Dalam kondisi normal, pembelajaran menggunakan sistem blended learning (pembelajaran bauran). Sebanyak 75 persen dari alokasi waktu dilaksanakan secara tatap muka, sementara 25 persen sisanya secara daring. Kini berbalik 180 derajat, seluruh aktivitas pembelajaran menjadi 94,3 persen dilakukan secara daring

Hubungan ketiga faktor tersebut, Islamic source (Al-Qur'an dan al-Hadits) sebagai sumber, human needs (sumber daya manusia) sebagai proses keberlangsungan hidup manusia, dan teknologi sebagai produk ilmu pengetahuan adalah formula untuk menentukan paradigma baru pendidikan Islam di era kontemporer. Perpaduan yang harmonis ketiganya tidak menutup kemungkinan mengupayakan terjadinya proses integrasiinterkoneksi, yang memberikan tawaran pendekatan baru (new approach) apa yang disebut model pendidikan Islam abad ke-21 yang lebih bersifat inklusif, aktual, akomodatif, dan problem solving di mana satu dengan yang lain saling melengkapi (Kementerian Pendidikan dan Kebudayaan Republik Indonesia, 2020).

Hal ini juga sejalan dengan pemanfaatan teknologi pembelajaran sebagai media di luar situasi kelas dalam yaitu: Pemanfaatan diluar kelas secara terkontrol 
merupakan teknologi pembelajaran sebagai media digunakan dalam serangkaian kegiatan yang diatur secara sistematik untuk mencapai tujuan pembelajaran yang telah ditentukan untuk dipakai oleh sasaran pemakai (siswa) dengan mengikuti pola dan prosedur pembelajaran tertentu hingga mereka dapat mencapai tujuan pembelajaran tersebut.

Berbagai media pembelajaran pun dapat dicoba dan digunakan di antaranya, e-learning, aplikasi zoom, google meet, google classrom, skype, youtube, whatsaap, dan sejenisnya. Sarana-sarana tersebut dapat digunakan secara maksimal. Misalnya pendidik membuat konten video kreatif, podcast, spotify misalnya sebagai materi pembelajaran. Dalam hal ini, pendidik harus lebih persuasif dalam menggaet perhatian peserta didik agar semakin tertarik dengan materi tersebut. Sehingga dengan adanya penerapan model pembelajaran seperti itu, membuat peserta didik tidak merasa bosan dalam mengikuti pembelajaran secara online. Oleh karena itu, kemampuan dalam memanfaatkan teknologi menjadi urgen dikala pandemi Covid-19 ini.

Meskipun demikian, dalam pembelajaran daring selama masa pandemi ini guru tidak bisa sepenuhnya memantau siswa terkait sebelum, proses dan sesudah pembelajaran daring, ada atau tidaknya perubahan pola-pola perbuatan, nilai-nilai, pengertian-pengertian, sikap-sikap, apresiasi dan keterampilan setelah pembelajaran.

Dalam sistem pendidikan nasional rumusan tujuan pendidikan mengacu pada klasifikasi hasil belajar dari Taksonomi Bloom yang secara garis besar yaitu aspek kognitif, aspek afektif dan aspek psikomotorik. Berdasarkan klasifikasi tersebut dan pendapat beberapa guru jika hasil belajar dilihat dari Taksonomi Bloom maka aspek kognitif yang seharusnya bisa mencapai mengetahui, memahami, menerapkan, menganalisis dan mengevaluasi hanya mencapai mengetahui dan memahami saja. Kemudian aspek afektifnya yang seharusnya bisa mencapai menerima, merespon, menghargai dan mengorganisasikan hanya mencapai menerima saja. Sedangkan aspek psikomotorik yang seharusnya bisa mencapai meniru, manipulasi, presisi, artikulasi dan naturalisasi hanya mencapai meniru. 
Guru harus mampu berinovasi dalam pembelajaran, mengembangkan metode, strategi, model, dan media sesuai karakteristik dan kebutuhan siswa (Muhammad, 2020). Hal itulah menjadi peluang bagi guru khususnya PAI untuk mengembangkan dalam metode pembelajaran jarak jauh. Kemudian dalam pembelajaran guru perlu lebih kreatif dan inovatif dalam mengeksplor aktivitas belajar mengajar (Arifa, 2020). Adapun kompetensi guru dalam pembelajaran jarak jauh juga menjadi penentu utama keberhasilan proses pembelajaran sehingga guru perlu memperkaya kompetensi dan meningkatkan keterampilan (Wahyono et al., 2020).

Kompetensi yang diperlukan dalam pembelajaran jarak jauh salah satunya adalah kompetensi digital. Kompetensi digital sangat diperlukan untuk memanfaatkan media digital dalam pembelajaran jarak jauh seperti keterampilan menyampaikan pengetahuan secara efektif, efisen, tepat, kritis, dan kreatif; mengelola informasi; berkolaborasi; membuat konten sesuai kebutuhan siswa, dan membagikan dimedia yang tepat (Hidayat \& Khotimah, 2019) .

Pemanfaatan teknologi informasi sangat berperan dalam pembelajaran jarak jauh. Teknologi informasi yang sudah berkembang pesat dapat dimanfaaatkan dalam proses pembelajaran (Sofwan Nugraha \& Supriadi dan Saepul Anwar, 2014). Pembelajaran berbasis digital menjadi salah satu alternatif pembelajaran PAI zaman digital (Prawiyogi, Anggi Giri, 2020). Pemanfaatan pembelajaran berbasis digital merupakan langkah untuk berani berinovasi, berkreativitas. Pemanfaatan teknologi tersebut sebagai peluang pengembangan metode pembelajaran PAI.

\section{SIMPULAN}

Dengan adanya pandemi Covid-19 memberikan hikmah bagi kehidupan baik dalam pendidikan dan lainnya. Perubahan dalam model dan karakteristik pembelajaran pendidikan Agama Islam juga berubah muali Pembelajaran dari rumah (study for home), mengharuskan orang tua lebih intens memonitoring perkembangan belajar anaknya secara langsung. Hal ini akan menimbulkan komunikasi yang harmonis dan kedekatan batin lebih erat antara anak dan orang tua. Memang pendidikan keluarga (family education) sejatinya adalah institusi pertama bagi anak dalam mengenyam pendidikan pertamanya. Paradigma 
pendidikan yang ditimpakan kepada sekolah dan guru, perlahan-lahan dipatahkan oleh pandemi ini. Terbukti, bahwa peran orang tua dan anak itu sendiri menjadi yang paling utama.

Selain itu, dalam perubahan model dan karakterisik ini pun seluruh proses kegiatan belajar mengajar dilakukan dengan jarak jauh secara online. Mulai dari pemberian materi dan tugas, pengerjaan dan pengumpulan tugas hingga pembagian hasil belajar (raport). Dalam pembelajaran daring ini sarana utama yang dibutuhkan adalah teknologi berbasis internet.

\section{DAFTAR RUJUKAN}

Aji, R. H. S. (2020). Dampak Covid-19 pada Pendidkan di Indonesia: Sekolah, Keterampilan, dan Proses Pembelajaran. SALAM: Jurnal Sosial \& Budaya Syar-I.

Arifa, F. N. (2020). Tantangan Pelaksanaan Kebijakan Belajar Dari Rumah Dalam Masa Darurat Covid-19. Info Singkat;Kajian Singkat Terhadap Isu Aktual Dan Strategis, XII(7/I), 6. http://berkas.dpr.go.id/puslit/files/info_singkat/Info Singkat-XII-7-I-P3DIApril-2020-1953.pdf

BUDI, S., \& Anshori, I. (2020). Analisis Efektifitas Pembelajaran Online pada Masa Pandemi Covid-19. Fikrotuna, 11(01). http://ejournal.kopertais4.or.id/madura/index.php/fikrotuna/article/view/3893

C, D. B. (2020). Analisis Keefektifan pembelajaran Online di Masa Pandemi Covid-19. Jurnal Pendidikan Guru Sekolah Dasar.

Inas Wydianuratikah. (2020). 94,3 Persen Perguruan Tinggi Lakukan Pembelajaran Daring. Republika Online. https://www.republika.co.id/berita/q9q641335/943-persen-perguruan-tinggilakukan-pembelajaran-daring

Kementerian Pendidikan dan Kebudayaan Republik Indonesia. (2020). SE Mendikbud: Pembelajaran secara Daring dan Bekerja dari Rumah untuk Mencegah Penyebaran Covid-19. Mendikbud RI, 1-2. https://www.kemdikbud.go.id

Pratiwi Wiwik. (2017). Konsep Bermain Pada Anak Usia Dini. Manajemen Pendidikan Islam, 5, 106-117.

Prawiyogi, Anggi Giri, D. (2020). Efektifitas Pembelajaran Jarak Jauh Terhadap Pembelajaran Peserta didik di SDIT Purwakarta. JPD: Jurnal Pendidikan Dasar.

Sofwan Nugraha, M., \& Supriadi dan Saepul Anwar, U. (2014). PEMBELAJRAN PAI BERBASIS MEDIA DIGITAL (Studi Deskriptip terhadap Pembelajaran PAI di SMA Alfa Centauri Bandung). Jurnal Pendidikan Agama Islam Ta'lim, 12(1), 55-67. 
Suyanto, A. H., SUHAT, S., Soekartawi, S., Librero, F., Puspianto, A., Pendidikan, S. E. M., Nomor, K., Mahmud, K., Gope, K., Kusmana, A., Hendrastomo, G., Epignosis, L. L. C., Andersson, A., Al-Hujran, O., Aloudat, A., Al-Hennawi, H., \& Ismail, H. N. (2008). Tahun 2020 tentang Pelaksanaan Kebijakan Pendidikan Dalam Masa Darurat Penyebaran. Majalah Ilmiah Pembelajaran, 4(1), 45-62.

Wahyono, P., Husamah, H., \& Budi, A. S. (2020). Guru profesional di masa pandemi COVID-19: Review implementasi, tantangan, dan solusi pembelajaran daring. Jurnal Pendidikan Profesi Guru, 1(1), 51-65. http://ejournal.umm.ac.id/index.php/jppg/article/view/12462 